\section{Bacillus thuringiensis Insecticides: Source of 2-Aminoacetophenone Formation in Wine?}

Nora Horlacher, Katharina Link and Wolfgang Schwack ${ }^{*}$

Institute of Food Chemistry, University of Hohenheim, Garbenstr, 28, 70569 Stuttgart, Germany

*Corresponding author: Wolfgang Schwack, Institute of Food Chemistry, University of Hohenheim, Garbenstr, 28, 70569 Stuttgart, Germany, Tel: +49 711459 23979; Fax: +49 711459 24096; E-mail: wolfgang.schwack@uni-hohenheim.de

Received date: April 11, 2016; Accepted date: July 14, 2016; Published date: July 25, 2016

Copyright: (c) 2016 Horlacher N, et al. This is an open-access article distributed under the terms of the Creative Commons Attribution License, which permits unrestricted use, distribution, and reproduction in any medium, provided the original author and source are credited.

\begin{abstract}
2-Aminoacetophenone (AAP) is mainly responsible for the "untypical aging off-flavor" (UTA) in Vitis vinifera wines, a negative change in the wine bouquet, which is described by odor taints such as 'furniture polish', 'wet wool', 'acacia blossom' or 'mothball'. AAP formation can be caused by photooxidation of tryptophan (TRP), which was previously shown under model conditions, by exposing free and lysozyme-bound tryptophan to UV light to be stored in model wine containing tartaric acid, sulphur dioxide and ethanol. The aim of the present study was to demonstrate the formation of AAP from Bacillus thuringiensis (Bt) as TRP source and, therefore, to identify $B t$ as a possible reason for UTA appearance in wine. Bt produces toxins and spores during its sporulation phase. The toxins are proteins, which include a number of TRP residues and which are, besides the spores, responsible for its toxicity towards insects. In viticulture, $B t$ based products are used to fight the European grape vine moth. Applied on grapes, $B t$ is exposed to sunlight, where Bt-bound TRP might be photooxidized yielding AAP precursors, which are released into the grape must and transformed to AAP during acidic wine storage. To prove this hypothesis, UV irradiated and non-irradiated $B t$ spray liquids were first transformed into model wines, which then were stored in the absence of light. Non-irradiated Bt spray liquids produced AAP, but prior UV light exposure prevented AAP formation. In a second step, harvested grapes were studied, non-sprayed or sprayed with $B t$, treated with or without UV irradiation and processed into wines. Similarly high AAP concentrations were obtained in all wines independent of the treatment with $B t$ or UV light, indicating that AAP precursors were already present on the studied grapes. However, the application of $B t$ in this study did not further enhance AAP formation, suggesting that additional factors such as aging processes of $B t$ residues in the vineyard might be involved.
\end{abstract}

Keywords: Untypical aging off-flavor; UTA; Bacillus thuringiensis, Biological insecticide; 2-aminoacetophenone; Photooxidation; Tryptophan; Wine

\section{Introduction}

The so-called "untypical aging off-flavor" (UTA) in wine is a negative change in the wine bouquet developed during storage, which leads to a considerable loss of wine quality. A correlation between the appearance of UTA and the formation of 2-aminoacetophenone (AAP) in wine has been identified [1,2]; therefore, numerous studies concerning the source and formation pathways of AAP have been conducted with the aim of creating new knowledge about, and ultimately preventing the development of UTA [3-7]. However, the reasons for the formation of AAP and the associated appearance of UTA in wine have not yet been clarified in detail. In a previous publication, we showed that AAP can be formed by UV light irradiation of free and lysozyme-bound tryptophan (TRP) after transformation into model wine and storage [8]. However, an appropriate TRP source present under real-world conditions has still not been identified. Possible sources include grape proteins or microbial proteins present on the surface of grapes. After exposure to sunlight, potential AAP precursors are formed and, after extraction into the grape must, these precursors are transformed into AAP during wine storage.

The aim of the present study was to identify the biological insecticide Bacillus thuringiensis $(B t)$ as an appropriate TRP source for the production of AAP. $B t$ insecticides are widely used in agriculture, and in viticulture they are used to control infestations by the European grape vine moth. In the European Union, various strains of $B t$ subsp. aizawai, kurstaki, israeliensis and tenebrionis are approved for use as active substances [9]. For German viticulture, Bt serovars kurstaki (HD-1) or aizawai (ABTS 1857) are authorized [10]. The formulated insecticides comprise a mixture of spores and protein crystals, but also vegetative cells, cell debris, fermentation media, and formulation additives can be contained [11]. The protein crystals formed by $B t$ during sporulation primarily consist of several smaller proteins, called $\delta$-endotoxins, which are toxic towards insects [11]. Endotoxins such as the CrylAa and CrylAb toxins include 18 and 17 TRP residues, respectively [12-15]. The degradation of up to $60 \%$ of TRP residues in purified $B t$ protein crystals by sunlight exposure already has been previously reported $[16,17]$. However, the related AAP formation during wine storage has not been investigated yet. Therefore, in our study, different Bt spray liquids were exposed to UV light, both in solution or after application onto grapes, and stored after transformation into model wine or wine, respectively. AAP formation was then determined after different periods of storage.

\section{Materials and Methods}

\section{Materials and samples}

2-Aminoacetophenone (AAP) (98\%), L-tryptophan ( $\geq 99.5 \%$ ), ethanol $(\geq 99.8 \%$ ), toluene (for pesticide residue analysis), t-butyl 
methyl ether (TBME) ( $\geq 99.8 \%$ ), hexane $(\geq 95 \%)$ and magnesium sulfate anhydrous $(\geq 97 \%)$ were obtained from Sigma-Aldrich (Steinheim, Germany). 2-amino-4-methoxyacetophenone (MeOAAP) (97\%) was from abcr (Karlsruhe, Germany). Paraffin oil (Ph. eur.) and methylene chloride $(\geq 99.9 \%)$ were purchased from Carl Roth (Karlsruhe, Germany), sodium hydroxide pellets $(\geq 99 \%)$, sodium chloride $(\geq 99.5 \%)$ and HPTLC silica gel $60 \mathrm{NH}_{2}$ plates were purchased from Merck (Darmstadt, Germany). L(+)-tartaric acid (pure) and magnesium chloride hexahydrate (pure) were from AppliChem (Darmstadt, Germany). Potassium pyrosulfite and selected yeast liquid "Burgund" were obtained from Hefereinzucht Schlag (Aalen, Germany). Purified water was obtained from a Water Synergy ultrapure water system (Merck Millipore, Schwalbach, Germany) Bacillus thuringiensis formulations were purchased from local distributors, three formulations were used. Two water-dispersible granules containing Bacillus thuringiensis subsp. aizawai $\left(540 \mathrm{~g} \mathrm{~kg}^{-1}\right)$, further referred to as $B t 1$ and $B t 2$, and one oil suspension containing $B t$ subsp. kurstaki (33.2 $\left.\mathrm{g} \mathrm{L}^{-1}\right)$, further referred to as $B t 3$ were used. Grapes of Vitis vinifera L. var. Thompson Seedless (syn. Sultanina), grown in Turkey were obtained from a local supermarket.

\section{Irradiation and Storage Experiments}

\section{Irradiation of $B t$ spray liquids and storage under model wine conditions}

$B t$ spray liquids were prepared according to the manufacturers' specifications in concentrations of 1.0, 1.6, and $1.25 \mathrm{~g} \mathrm{~L}^{-1}$ for $B t 1, B t 2$, and $B t 3$, respectively. For irradiation, $35 \mathrm{~mL}$ of the $B t$ spray liquid was exposed to artificial sunlight, following the irradiation procedure described previously [8], with light intensities of $19.7 \mathrm{~mW} \mathrm{~cm}^{-2}$ (UVA) and $1.01 \mathrm{~mW} \mathrm{~cm}^{-2}$ (UVB) and an irradiation time of $24 \mathrm{~h}$. For storage under model wine conditions according to [8], $30 \mathrm{~mL}$ of the irradiated $B t$ spray liquid was transformed into model wine by the addition of $400 \mu \mathrm{L}$ of an aqueous L-(+)-tartaric acid solution $\left(270 \mathrm{~g} \mathrm{~L}^{-1}\right), 400 \mu \mathrm{L}$ of an aqueous potassium pyrosulfite solution $\left(8.66 \mathrm{~g} \mathrm{~L}^{-1}\right)$, and $5.2 \mathrm{~mL}$ of ethanol. The $\mathrm{pH}$ was adjusted to 3.3 with $1 \mathrm{M} \mathrm{NaOH}$ solution. The volume was adjusted to $40 \mathrm{~mL}$ with the addition of water, resulting in a final concentration of $2.7 \mathrm{~g} \mathrm{~L}^{-1} \mathrm{~L}-(+)$-tartaric acid, $50 \mathrm{mg} \mathrm{L}^{-1} \mathrm{SO}_{2}$ and $13 \%$ (v.) ethanol (according to [18]). For $B t 1$ spray liquids, model wine was also prepared without the addition of sulfite. The model wines were stored in $50 \mathrm{~mL}$ screw-capped brown glass vials in the absence of light at $40^{\circ} \mathrm{C}$. After 6 and 8 weeks of storage, $30 \mathrm{~mL}$ of each model wine was prepared for AAP analysis. Non-irradiated spray liquids were transformed into model wines and stored, using the same procedure outlined above.

\section{Irradiation of $B t$ treated grapes and preparation of wines}

$B t 2$ spray liquid was prepared as described in the former section and was applied onto grapes using a $500 \mathrm{~mL}$ LDPE (low-density polyethylene) spray bottle with a PP (polypropylene) spray head (VWR International, Darmstadt, Germany). The spray liquid was applied until grapes were dripping wet, while attention was paid to ensure even distribution. Grapes were allowed to air dry and were then divided into two groups. One group was irradiated and the other group was stored in the absence of light. Irradiation was performed in a self-constructed solar simulator consisting of two identical light sources (UVB broadband lamps TL 100W/12 R17d UVB; length: $1780 \mathrm{~mm}$, diameter: $40 \mathrm{~mm}$; Philips, Hamburg, Germany) emitting UVB $\left(0.38 \mathrm{~mW} / \mathrm{cm}^{2}\right)$ and UVA $\left(0.38 \mathrm{~mW} / \mathrm{cm}^{2}\right)$ light. The distance between the lamps was 28 $\mathrm{cm}$. Grapes were hung on a rod and positioned equidistant between the two lamps. The ground was covered with aluminum foil and the entire construction was covered with an aluminum hood. Irradiation was performed for 24 hours. Additionally, grapes were irradiated, without previously applying the spray liquid. Afterwards, irradiated and non-irradiated grapes were prepared for winemaking. Therefore, $1.5 \mathrm{~kg}$ of grapes were placed in commonly available freezer bags, frozen at $-20^{\circ} \mathrm{C}$ and thawed to disrupt cells through ice crystal formation and to make mashing by hand easier. Grapes were crushed by hand in the freezer bags, and stalks were not removed. The mash was sulfurized by adding $120 \mathrm{mg}$ of potassium pyrosulfite (equivalent to $70 \mathrm{mg} \mathrm{SO}$ ), mixed and allowed to stand for $5 \mathrm{~h}$ in the freezer bags. Thereafter, the mash was transferred to a nylon bag (Hefereinzucht Schlag, Aalen, Germany), pressed by hand, and the obtained must was collected in a $1 \mathrm{~L}$ glass bottle. The must was allowed to stand for another hour to allow settling of solids and particles to the bottom, whereupon the clear must was decanted into another $1 \mathrm{~L}$ glass bottle, followed by inoculation with $300 \mu \mathrm{L}$ selected yeast liquid for fermentation. The bottle was closed with a stopper (inner diameter 44 $\mathrm{mm}$, Hefereinzucht Schlag, Aalen, Germany) and a water-filled airlock (shaft $9 \mathrm{~mm}$, Hefereinzucht Schlag, Aalen, Germany). Fermentation was performed in a temperature controlled cabinet at $19^{\circ} \mathrm{C}$ in the absence of light. Bottles were stirred gently once a day. After storage for 20 days, lees were separated by decanting the wine into a $500 \mathrm{~mL}$ glass bottle. Potassium pyrosulfite $(120 \mathrm{mg})$ was added, and the bottle was closed with a PP screw cap. After defined periods of storage (5 and 8 weeks) at $19^{\circ} \mathrm{C}, 30 \mathrm{~mL}$ aliquots were prepared for AAP analysis. After 8 weeks of storage, the wines were placed into an oven, where they were stored for another 6 weeks at $40^{\circ} \mathrm{C}$, whereupon aliquots were diluted 1:2.5 with water for AAP analysis.

\section{Irradiation of tryptophan and storage in model wine}

L-tryptophan (92 mg, $0.45 \mathrm{mmol}$ ) was dissolved in $100 \mathrm{~mL}$ water. Irradiation and storage in model wine was carried out in the same manner as described above for $B t$ spray liquids. Additionally, nonirradiated samples were analyzed immediately after transformation into model wine and after storage for 8 weeks. For AAP analysis, samples of model wine prepared from the irradiated TRP solutions were diluted 1:500 with model wine, while model wine samples prepared from non-irradiated TRP solution were analyzed directly.

\section{AAP analysis}

For AAP analysis, $30 \mathrm{~mL}$ of wines and model wines were prepared and analyzed as described in an earlier publication [19]. For highperformance thin-layer chromatography (HPTLC), however, some minor modifications were made. Due to the presence of interfering $B t$ matrix compounds, the mobile phase composition, which was methylene chloride/toluene $(7+3, v / v)$ for real wine extracts [19], was optimized to ensure the AAP analysis was free of interferences. For extracts of model wines containing $B t 1, B t 2$, or solutions of TRP, development was performed with methylene chloride/toluene $(5+5$, $\mathrm{v} / \mathrm{v}$ ) to a migration distance of $60 \mathrm{~mm}$. For extracts of model wines containing the oil suspension Bt3, HPTLC plates were first developed with hexane to a migration distance of $80 \mathrm{~mm}$. After drying the plates inside a fume cupboard for $10 \mathrm{~min}$, a second development was performed with methylene chloride/toluene/TBME $(6+4+0.08, \mathrm{v} / \mathrm{v} / \mathrm{v})$ to a migration distance of $60 \mathrm{~mm}$. For wine extracts, the mobile phase was methylene chloride/toluene $(5.5+4.5, \mathrm{v} / \mathrm{v})$ with a migration distance of $60 \mathrm{~mm}$. 
Page 3 of 5

\section{Tryptophan analysis}

The determination of TRP content of the commercial $B t$ insecticides was carried out according to [20]. TRP was determined before and after alkaline hydrolysis to acquire percentages of free and total TRP.

\section{Statistics}

The significance of differences were tested with a two-sample t-test $(\mathrm{p}=0.05)$, using IBM SPSS Statistics for windows, Version 19.0.

\section{Results and Discussion}

\section{Solution experiments}

The active ingredients in the Bacillus thuringiensis formulations studied here included $540 \mathrm{~g} \mathrm{~kg}^{-1} B t$ subsp aizawai in $B t 1$ and $B t 2$ and $33.2 \mathrm{~g} \mathrm{~L}^{-1}$ Bt subsp kurstaki in Bt3. As further information concerning the composition of the formulations was not known, the formulations were analyzed for their free and protein-bound TRP. After alkaline hydrolysis, the total TRP concentrations were $1.8,1.7$, and $1.4 \mathrm{mg} \mathrm{g}^{-1}$ for the $B t 1, B t 2$, and $B t 3$ formulations, respectively, resulting in TRP concentrations of $1.8,2.7$, and $1.8 \mathrm{mg} \mathrm{L}^{-1}$ in the prepared spray liquids. The values of TRP determined before hydrolysis were below the limit of quantification (LOQ), which was $0.1 \mathrm{mg} \mathrm{g}^{-1}$ formulation. Hence, it can be concluded that most TRP in the formulations was proteinbound.

To determine if the $B t$ formulations already contained potential AAP precursors and whether their storage in model wine yielded AAP production, they were first studied without being UV irradiated. To this end, spray liquids were prepared according to the manufacturers' instructions, transformed into model wines, and stored at $40^{\circ} \mathrm{C}$ in the absence of light. After six weeks, both $B t 1$ and $B t 2$ model wines revealed considerable AAP formation, while the AAP concentrations did not differ significantly between the two formulations $(p>0.05)$ (Table 1). After 8 weeks, AAP concentrations were further increased, but were almost twice as high in $B t 2$ as in $B t 1$ model wines $(\mathrm{p}<0.05)$, which could be attributed to greater amounts of formulation in the prepared $B t 2$ spray liquid $\left(1.6 \mathrm{~g} \mathrm{~L}^{-1}\right)$ than in the $B t 1$ spray liquid $(1.0 \mathrm{~g}$ $\left.\mathrm{L}^{-1}\right)$. However, when the amount of AAP was calculated per $\mathrm{g} B t$ formulation, both formulations showed approximately $0.8 \mu \mathrm{g}$ AAP g ${ }^{-1}$ $B t$ formulation, with no significant differences between $B t 1$ and $B t 2$ $(\mathrm{p}>0.05)$ (Table 1). This also held true for $B t 1$ model wine prepared without the addition of $\mathrm{SO}_{2}$ ( $\left.\mathrm{p}>0.05\right)$. In the $B t 3$ model wine, the AAP formation was distinctly lower than in $B t 1$ and $B t 2$ model wine, but followed a similar trend; AAP increased from below limit of detection (LOD) to below LOQ after 6 weeks of storage and remained below LOQ even after 8 weeks (Table 1).

To study the influence of UV light exposure on the formation of AAP, $B t$ spray liquids were irradiated, transformed into model wines, and stored. However, the results clearly showed that irradiation did not influence AAP formation, as AAP remained below the LOD in $B t 1$ and $B t 3$ model wines and below LOQ in $B t 2$ model wine during storage (Table 1). These results were truly surprising, as irradiation of free and lysozyme-bound TRP yielded AAP, while non-irradiated samples did not result in detectable AAP levels [8]. The conditions during irradiation and storage, however, were different in the present study. The UV light source was more intense in this study, and irradiations were performed in the absence of the photosensitizer riboflavin, and irradiation and storage times were expanded to enhance AAP formation.

\begin{tabular}{|c|c|c|c|c|c|c|c|}
\hline \multicolumn{8}{|c|}{ AAP concentration $\mu \mathrm{g} \mathrm{L}^{-1}$ model wine or $\left[\mu \mathrm{g} \mathrm{g}^{-1} \mathrm{Bt}\right.$ formulation] } \\
\hline \multirow[b]{2}{*}{$\begin{array}{l}\text { Spray } \\
\text { liquid }\end{array}$} & \multicolumn{5}{|c|}{ Non-irradiated } & \multicolumn{2}{|l|}{ Irradiated } \\
\hline & $\begin{array}{l}\text { Non- } \\
\text { stored }\end{array}$ & $\begin{array}{l}\text { Store } \\
\text { week }\end{array}$ & $\begin{array}{l}d \text { for } 6 \\
s\end{array}$ & $\begin{array}{l}\text { Store } \\
\text { weeks }\end{array}$ & for 8 & $\begin{array}{l}\text { Stored for } \\
6 \text { weeks }\end{array}$ & $\begin{array}{l}\text { Stored } \\
\text { for } 8 \\
\text { weeks }\end{array}$ \\
\hline Bt1 & $\begin{array}{l}<L^{\prime} D^{*} \\
(n=7)\end{array}$ & $\begin{array}{l}0.50 \\
{[0.66} \\
(n=2)\end{array}$ & $\left.\begin{array}{ll} \pm & 0.02 \\
\pm & 0.02\end{array}\right]$ & $\begin{array}{l}0.57 \\
{[0.76} \\
(n=7)\end{array}$ & $\begin{array}{ll} \pm & 0.08 \\
\pm & 0.10]\end{array}$ & $\begin{array}{l}<\mathrm{LOD} \\
(\mathrm{n}=2)\end{array}$ & $\begin{array}{l}<L O D \\
(n=7)\end{array}$ \\
\hline$B t 1^{+}$ & $\begin{array}{l}<\mathrm{LOD} \\
(\mathrm{n}=2)\end{array}$ & & - & $\begin{array}{l}0.63 \\
{[0.83} \\
(n=2)\end{array}$ & $\left.\begin{array}{ll} \pm & 0.04 \\
\pm & 0.05\end{array}\right]$ & - & $\begin{array}{l}<L O D \\
(n=2)\end{array}$ \\
\hline$B t 2$ & $\begin{array}{l}<\mathrm{LOQ}^{*} \\
(\mathrm{n}=7)\end{array}$ & $\begin{array}{l}0.64 \\
{[0.53} \\
(n=2)\end{array}$ & $\begin{array}{ll} \pm & 0.05 \\
\pm & 0.04]\end{array}$ & $\begin{array}{l}0.97 \\
{[0.81} \\
(n=7)\end{array}$ & $\begin{array}{ll} \pm & 0.13 \\
\pm & 0.11]\end{array}$ & $\begin{array}{l}<L O Q \\
(n=2)\end{array}$ & $\begin{array}{l}<L O Q \\
(n=7)\end{array}$ \\
\hline$B t 3$ & $\begin{array}{l}<\mathrm{LOD} \\
(\mathrm{n}=7)\end{array}$ & $<\mathrm{LOQ}$ & $(n=2)$ & $<\mathrm{LOQ}$ & $(n=7)$ & $\begin{array}{l}<L O D \\
(n=1)\end{array}$ & $\begin{array}{l}<L O D \\
(n=7)\end{array}$ \\
\hline
\end{tabular}

Table 1: AAP formation from $B t$ spray liquids. Irradiated or nonirradiated Bt spray liquids were stored in model wine at $40^{\circ} \mathrm{C}$ for defined periods of time. ${ }^{+}$Storage was performed in the absence of sulfite (model wine: $2.7 \mathrm{~g} \mathrm{~L}^{-1} \mathrm{~L}-(+)$-tartaric acid, $13 \%$ (v.) ethanol; $\mathrm{pH}$ 3.3 [18]). ${ }^{*}$ Limit of detection (LOD) and limit of quantitation (LOQ) were determined to 0.1 and $0.3 \mu \mathrm{g} \mathrm{L}-1$ model wine, according to [19].

In order to validate the altered experimental conditions, free TRP was studied again, and the results confirmed that TRP photooxidation is a prerequisite for relevant AAP formation. Although small amounts of AAP $\left(2.8 \pm 0.1 \mu \mathrm{g} \mathrm{L}^{-1}, \mathrm{n}=2\right)$ were formed in non-irradiated TRP samples after 8 weeks of storage in model wine, the AAP concentration was $297.5 \pm 7.1 \mu \mathrm{g} \mathrm{L}^{-1}(\mathrm{n}=2)$ in model wines prepared from an irradiated TRP solution and stored for 8 weeks. Thus, the model was still valid, even without the addition of riboflavin.

One explanation why this model could not be transferred to $B t$ formulations may be related to the photostability of $B t$-bound TRP residues. Although degradation of TRP residues in dry $B t$ protein crystals has been reported in the literature $[16,17]$, these authors also report that TRP did not undergo photodegradation if the protein crystals were kept under water during irradiation [17]. This was attributed to the decreasing availability of effective oxygen to the crystals, as the authors assumed that photodegradation of TRP follows the singlet oxygen mediated pathway $[16,17]$. Furthermore, the composition of the studied $B t$ formulations and whether or not they contain formulation additives, is not known. The presence of UV protectants, which may have been added to $B t$ formulations [21] to increase their stability in the field, could prevent photooxidation of TRP, thereby preventing the formation of AAP. When non-irradiated $B t$ formulations were stored in model wine however, AAP formation occurred. Sulfite-dependent TRP degradation [22] and AAP formation from free TRP [3] have been previously reported. However, sulfurized wines and model wines spiked with free TRP only revealed low levels of AAP after storage [3]. The sulfite-dependent AAP formation could be excluded by the present experiments, as the $\mathrm{SO}_{2}$-free model wine prepared from $B t 1$ spray liquid showed the same AAP values as a corresponding model wine prepared with $\mathrm{SO}_{2}$ (Table 1). 


\section{Grape experiments}

To better simulate the conditions existing in a vineyard, spray liquids were applied onto harvested grapes and allowed to dry. The grapes were subsequently UV irradiated. Therefore, $B t$ was present in dry form on the grapes' surface; for dry $B t$ protein crystals, the degradation of TRP residues has been previously reported [16]. Additionally, sprayed grapes were protected from light during storage. Thereafter, wines were prepared from irradiated and non-irradiated grapes and stored at $19^{\circ} \mathrm{C}$ for up to 8 weeks, followed by storage of 6 weeks at $40^{\circ} \mathrm{C}$. The original grapes (not sprayed) were also irradiated, transformed into wine, and stored. None of the wines showed a significant AAP formation when stored at a temperature of $19^{\circ} \mathrm{C}$; after 8 weeks AAP was still $<$ LOQ in all wines (Table 2). In order to examine the reinforcing effect of heat on AAP formation [8], the storage temperature was raised to $40^{\circ} \mathrm{C}$. After six weeks at $40^{\circ} \mathrm{C}$, AAP formation was well detectable in all wines, but its formation was independent of $B t$ treatment or irradiation (Table 2), and there were no significant differences in the AAP concentration between any of the wines ( $p>0.05$ ). In wines made from unsprayed grapes, AAP formation can only be explained by the presence of another TRP source. This could be in the form of other proteins present on the surface of grapes or even in the form of $B t$ residues from former applications in the vineyard, which is difficult to analyze. In Turkey, where the grapes were grown, the application of $B t$ is authorized [23].

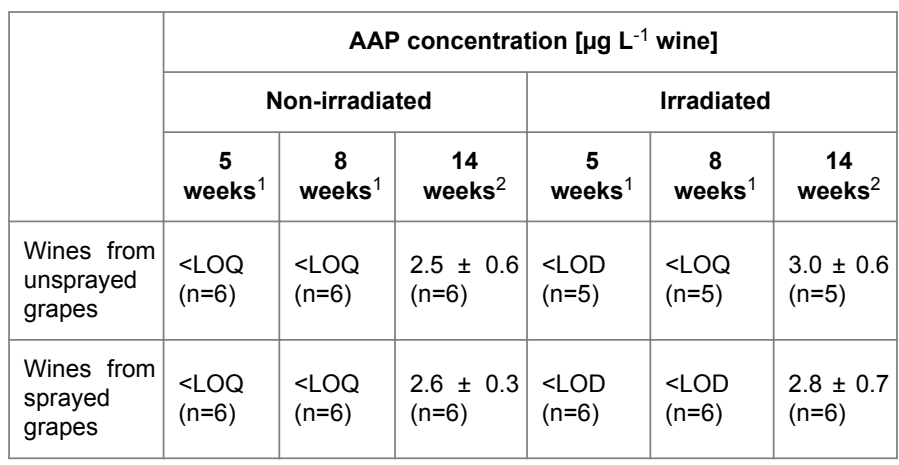

Table 2: AAP formation in wines made from sprayed and unsprayed grapes. After irradiation or storage, wines were prepared and stored for 5 and 8 weeks at $19^{\circ} \mathrm{C}$ and for an additional 6 weeks at $40^{\circ} \mathrm{C}$ (a total of 14 weeks). ${ }^{1}$ Storage of wines at $19^{\circ} \mathrm{C} .{ }^{2}$ Storage of wines at $19^{\circ} \mathrm{C}$ for 8 weeks plus storage at $40^{\circ} \mathrm{C}$ for 6 weeks.

In any case, AAP precursors were clearly already present on the studied grapes, but the fresh application of $B t$, whether followed by exposure to UV light or not, did not further enhance AAP formation. However, this study was conducted under model conditions without taking into account all of the influences that exist in the vineyard. In particular, $B t$ residues on grapes might be subjected to aging processes, which could not be simulated during the present study, because harvested grapes only survive for a couple of weeks. As reported in the literature, the field stability of $B t$ formulations, including their persistence on plant surfaces and their activity against target insects, is greatly influenced by environmental factors such as solar irradiation, rainfall or temperature [11]. Therefore, further studies are needed to prove or exclude $B t$ applications as a source of AAP precursors in wines.

\section{Conclusion}

From the results obtained in this study it remains unclear whether $B t$ insecticides could be responsible for UTA in wines. While AAP was indeed detectable in model wines containing $B t$ formulations, prior UV irradiation prevented the formation of AAP. Experiments with grapes processed into wines also clearly revealed AAP formation, but this was independent of $B t$ treatment and/or UV irradiation. Therefore, further studies are required to assess $B t$ aging processes and to follow and understand the fate of $B t$ residues on grapes over longer time periods.

\section{Acknowledgements}

We gratefully thank Dr. K. Schwadorf, State Institute for Agricultural Chemistry, University of Hohenheim (Stuttgart, Germany) for tryptophan analyses.

\section{Conflict of Interest Statement}

The authors of this publication declare that there is no conflict of interest.

\section{References}

1. Rapp A, Versini G, Ullemeyer H (1993) Causal component of untypical aging flavour (naphthalene note, hybrid note) of wine. Vitis 32: 61-62.

2. Christoph N, Bauer-Christoph C, Geßner M, Köhler HJ (1995) Die "Untypische Alterungsnote" im Wein Teil I: Untersuchungen zum Auftreten und zur sensorischen Charakterisierung der "Untypischen Alterungsnote". Rebe \& Wein 48: 350-356.

3. Christoph N, Bauer-Christoph C, Geßner M, Köhler HJ, Simat TJ, et al. (1998) Formation of 2-Aminoacetophenone and Formylaminoacetophenone in Wine by Reaction of Sulfurous Acid with Indole-3-Acetic Acid. Vitic Enol Sci 53: 79-86.

4. Hoenicke K, Borchert O, Grüning K, Simat TJ (2002) "Untypical aging off-flavor" in wine: synthesis of potential degradation compounds of indole-3-acetic acid and kynurenine and their evaluation as precursors of 2-aminoacetophenone. J Agric Food Chem 50: 4303-4309.

5. Geßner M, Köhler HJ, Christoph N, Bauer-Christoph C (1996) Die "Untypische Alterungsnote im Wein" Teil VII Untersuchungen zur Bildung von o-Aminoacetophenon aus Produkten des TryptophanStoffwechsels bei der alkoholischen Gärung. Rebe \& Wein 49: 251-255.

6. Dollmann B, Schmitt A, Köhler H, Schreier P (1996) Formation of the 'untypical aging off-flavour' in wine: Generation of 2-aminoacetophenone in model studies with Saccharomyces cerevisiae. Vitic Enol Sci 51: 122-125.

7. Christoph N, Bauer-Christoph C, Geßner M, Köhler HJ (1996) Die "Untypische Alterungsnote" im Wein Teil VI Untersuchungen zur Bildung von o-Aminoacetophenon aus Produkten des TryptophanStoffwechsels vor der alkoholischen Gärung. Rebe \& Wein 49: 246-250.

8. Horlacher N, Schwack W (2014) Photooxidation of tryptophan leading to 2-aminoacetophenone-a possible reason for the untypical aging off-flavor in wine. Photochem Photobiol 90: 1257-1263.

9. European Commission (2011) Commission Implementing Regulation (EU) No 540/2011 Off J Eur Union L153: 1-86.

10. http://www.bvl.bund.de/SharedDocs/Downloads/ 04_Pflanzenschutzmittel/psm_verz_3.html?nn=1798082

11. Glare TR, O'Callaghan M (2000) Bacillus thuringiensis: Biology, ecology and safety. Wiley.

12. http://www.uniprot.org/uniprot/P0A366

13. http://www.uniprot.org/uniprot/P0A367.

14. http://www.uniprot.org/uniprot/P0A370.

15. http://www.uniprot.org/uniprot/P0A372 
Citation: Horlacher N, Link K, Schwack W (2016) Bacillus thuringiensis Insecticides: Source of 2-Aminoacetophenone Formation in Wine? J Exp Food Chem 2: 113. doi:10.4172/2472-0542.1000113

Page 5 of 5

16. Pozsgay M, Fast P, Kaplan H, Carey PR (1987) The effect of sunlight on the protein crystals from Bacillus thuringiensis var. kurstaki HD1 and NRD12: a raman spectroscopic study. J Invertebr Pathol 50: 246-253.

17. Pusztai M, Fast P, Gringorten L, Kaplan H, Lessard T, et al. (1991) The mechanism of sunlight-mediated inactivation of Bacillus thuringiensis crystals. Biochem J 273: 43-47.

18. Schmarr HG, Ganß S, Sang W, Potouridis T (2007) Analysis of 2 aminoacetophenone in wine using a stable isotope dilution assay and multidimensional gas chromatography-mass spectrometry. J Chromatogr A 1150: 78-84.

19. Horlacher N, Schwack W (2016) Determination of 2 Aminoacetophenone in wine by high-performance thin-layer chromatography-fluorescence detection. J Chromatogr A 1432: 140-144.
20. European Commission (2009) Commission Regulation (EC) No 152/2009. Off J Eur Union L54: 32-37.

21. Burges HD, Jones KA (1998) Formulation of bacteria, viruses and protozoa to control insects. In: Formulation of Microbial Biopesticides: Beneficial microorganisms, nematodes and seed treatments. Kluwer.

22. Yang SF (1973) Destruction of tryptophan during the aerobic oxidation of sulfite ions. Environ Res 6: 395-402.

23. https://bkubeta.tarim.gov.tr/ 